\title{
Методика формування і розвитку мовленнсвої компетентності в усному китайському діалогічному мовленні майбутніх філологів-синологів на середньому рівні мовної підготовки
}

\author{
О. В. Асадчих, Ма Мінь, В. О. Філонова \\ Кафедра мов і літератур Далекого Сходу та Південно-Східної Азії Інституту філології \\ Київський національний університет імені Тараса Шевченка, м. Київ, Україна \\ Corresponding author. E-mail: nikka77@ukr.net
}

Paper received 24.10.19; Accepted for publication 10.11.19.

\section{https://doi.org/10.31174/SEND-PP2019-208VII85-02}

Анотація. У статті розглядаються особливості методики формування і розвитку мовленнєвої компетентності в усному китайському діалогічному мовленні майбутніх філологів-синологів на середньому рівні мовної підготовки, визначаються типи діалогічної взаємодії та подається підсистема вправ і завдань. Підсистема вправ і завдань для навчання усного китайського діалогічного мовлення розроблена згідно з типами діалогічної взаємодії, якими є інформативний, стимулювальний, кооперативний та дискутивний. До підсистеми увійшли рецептивно-репродуктивні, репродуктивно-продуктивні та продуктивні вправи, а за критерієм комунікативності - умовно-комунікативні, комунікативні вправи першого та другого рівнів.

Ключові слова: усне китайське діалогічне мовлення, філологи-синологи, навчання китайської мови в мовному ЗВО, типи діалогічної взаємодї, підсистема вправ $і$ завдань.

Постановка проблеми. Освітні програми для філологів свідчать, що ефективне діалогічне спілкування $є$ універсальною дидактичною метою навчання китайської мови в Україні: виконання вправ, читання текстів, творчі завдання у фінальному результаті повинні забезпечити українським студентам компетентність у діалогічному мовленні, маючи яку, вони вільно порозуміються $з$ китайськими колегами, синологами України і світу. А тому одним із найважливіших аспектів вивчення китайської мови філологами $є$ формування усномовленнєвої компетентності та оволодіння іії важливим компонентом - діалогічним мовленням.

Теоретичні засади навчання студентів-синологів діалогу зумовлюють розроблення авторської методики навчання студентів китайського діалогічного мовлення на середньому рівні мовної підготовки у вищій школі з позицій компетентнісного і комунікативного наукових підходів, яку необхідно реалізувати на основі:

- $\quad$ визначеної компетентності в усному китайському діалогічному мовленні студента,

- етапів навчання,

- $\quad$ 3' $\quad$ ясування дидактичних цілей і функцій викладача,

- уточненого змісту навчання,

- $\quad$ ключових принципів, методів і прийомів нав-

чання.

Відповідно до методичних засад навчання китайського усного діалогічного мовлення у студентів на середньому рівні мовної підготовки дидактичною метою є сформована усномовленнєва компетентність в діалогічному мовленні відповідно до типів діалогічної взаємодії. Окремими компонентами змісту навчання діалогічного мовлення $\epsilon$ :

1) знання про діалогічну єдність, типи діалогічної взаємодії, комунікативну мету мовлення в діалозі, функції репліки, механізм підтримання і розвитку діалогічної взаємодії у слуханні та говорінні;

2) уміння та навички слухання у процесі діалогічної взаємодії;

3) уміння та навички реплікування в діалозі;
4) уміння використовувати набір мовних засобів і композиційних структур для реалізації комунікативного наміру.

Така загальна характеристика $\epsilon$ необхідною для 3'ясування конкретних особливостей формування компетентності в китайському діалогічному мовленні.

Аналіз наукових досліджень та публікацій. В Україні навчання китайського діалогічного мовлення належить до загальної системи навчання іноземних мов. Науковці і викладачі (О. Асадчих, О. Білик, Т. Бондарчук, В. Голубець, І. Кіндрась, Г. Михайлюк, Л. Нечаєва, О. Озерська), які займаються проблемами навчання східних мов, вважають, що студенти повинні мати значний обсяг практичного діалогічного спілкування на основі вивчення положень теорії діалогу, щоб задовольнити потребу студента бути активним учасником міжкультурного спілкування.

У методиці навчання китайського мовлення важливе всебічне використання потенціалу діалогу між вчителем та студентом. Як пише Рональд Арнетт (Ronald Arnett), готовність розпочинати розмову про ідеї $\mathrm{i}$ ставити запитання є більш цінним умінням людини 3 вищою освітою, ніж сприйняття і розповсюдження нової інформації [4]. Цю позицію ми втілюємо в навчанні студентів діалогічного мовлення різних типів, акцентуючи увагу на запитаннях, обміні думками, враженнями, обговоренні і дискутуванні в формі діалогу.

Мета статті - подати особливості методики формування i розвитку мовленнєвої компетентності в усному китайському діалогічному мовленні майбутніх філологів-синологів на середньому рівні мовної підготовки, визначити типи діалогічної взаємодії та представити підсистему вправ і завдань.

Виклад основного матеріалу. Згідно з висновками психологів, філософів, лінгвістів та лінгводидактів визначено типи діалогічної взаємодії, які є змістом навчання усного китайського діалогічного мовлення (таб. 1). 
Таблиця 1. Типи діалогічної взаємодії як предмет навчання усного китайського мовлення

\begin{tabular}{|l|l|l|l|l|}
\hline & Інформативна & Стимулювальна & Кооперативна & Дискутивна \\
\hline $\begin{array}{l}\text { Комунікативний } \\
\text { намір }\end{array}$ & $\begin{array}{l}\text { довідатися, повідомити, } \\
\text { уточнити, узгодити }\end{array}$ & $\begin{array}{l}\text { прохати, наказува- } \\
\text { ти, радити, спону- } \\
\text { кати }\end{array}$ & $\begin{array}{l}\text { домовлятися, розділити } \\
\text { враження, поділитися } \\
\text { думками, судженнями }\end{array}$ & $\begin{array}{l}\text { переконувати, не } \\
\text { погоджуватися, } \\
\text { обстоювати думку, }\end{array}$ \\
\hline Загальні компо- \\
ненти
\end{tabular}

Спираючись на модель підготовки перекладачасинолога і специфікації знань, умінь та навичок, запропоновані Ігорем Кочергіним [1, с. 78-82], ми узагальнили практичні рекомендації автора і створили власний перелік компетентностей, які необхідно сформувати у філолога-синолога у процесі навчання в університеті (Таб. 2). При цьому ми розподілили компетентності за типом усного мовлення і вимогами до середнього рівня мовної підготовки, грунтуючись на знаннях, уміннях і навичках, сформованих на початковому етапі вивчення китайської мови.

Таблиця 2. Усномовленнсві компетентності філолога-синолога на середньому рівні мовної підготовки

\begin{tabular}{|c|c|}
\hline $\begin{array}{l}\text { Компетентність } \\
\text { аудіювання }\end{array}$ & 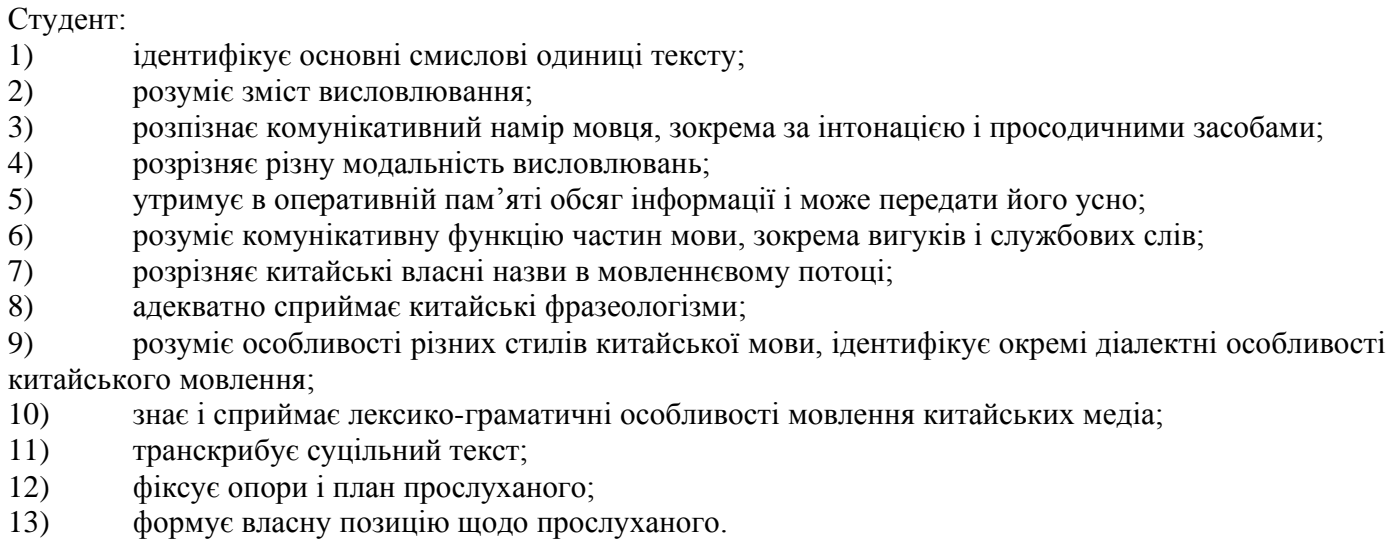 \\
\hline $\begin{array}{l}\text { Компетентність } \\
\text { говоріння }\end{array}$ & $\begin{array}{l}\text { Студент: } \\
\text { 1) правильно використовує орфоепічні правила, інтонацію, просодичні засоби для оформлення } \\
\text { висловлювання; } \\
\text { 2) } \quad \text { конструює монологічне та діалогічне мовлення за композиційними і мовними нормами; } \\
\text { 3) будує висловлювання різної модальності; } \\
\text { 4) виражає комунікативний намір за допомогою мовних одиниць; } \\
\text { 5) правильно використовує власні назви, фразеологізми; } \\
\text { 6) } \quad \text { оформлює емотивне мовлення із відповідним використанням вигуків, жестів і міміки; } \\
\text { 7) починає і завершує мовлення сталими зворотами, етикетними фразами; } \\
\text { використовує норми риторики. }\end{array}$ \\
\hline
\end{tabular}

Сприймання, розуміння, інтерпретація і конструювання усних висловлювань відбувається завдяки переведенню писемних конструкцій-зразків в усну форму мовлення. Завдяки цьому збагачуються висловлювання мовця і урізноманітнюється лексичний фонд усного мовлення. Тому усномовленнєві компетентності не можуть формуватися і розвиватися продуктивно, якщо одночасно не відбувається процес удосконалення писемного мовлення.

Згідно з уведеним нами визначенням «мовленнєвої компетентності в усному китайському діалогічному мовленні», ми створили перелік компонентів, які реалізуються в означеній компетентності (див. таб.3).

Розглянемо підсистему вправ для навчання усного китайського діалогічного мовлення студентів мовних ЗВО на середньому рівні вивчення китайської мови. Суб'єктами навчання є студенти 3-го курсу бакалаврі- ату спеціальності «Філологія». Викладання китайської мови триває упродовж 2-х семестрів, кількість кредитів ECTS - 9,5. Загальний обсяг- 366 годин. Всього аудиторних годин - 108 (усі практичні). Самостійна робота - 258 годин. Розподіл аудиторних i позааудиторних (самостійна робота) годин у кожному семестрі такий: 54 год. (1,5 години на тиждень) / 129 годин.

Обгрунтуємо типи вправ, які будемо використовувати в розробленій нами підсистемі вправ. Вправи зі спільними ознаками, підпорядковані певним критеріям, поєднуються у типи. Серед критеріїв, за якими визначаються типи вправ, $є$ основні та додаткові. У нашому дослідженні за критерієм спрямованості навчальної дії на видачу або отримання інформації визначаються рецептивно-репродуктивні, репродуктивно-продуктивні та продуктивні вправи [2; 3$]$. 
За критерієм комунікативності в нашому дослідженні визначаються умовно-комунікативні, комуні-

кативні вправи першого та другого рівнів.

Таблиця 3. Компетентність в усному китайському діалогічному мовленні

\begin{tabular}{|c|c|c|}
\hline $\begin{array}{l}\text { Загальні } \\
\text { компоненти }\end{array}$ & $>$ & $\begin{array}{l}\text { будує комунікативно доцільну стратегію мовленнєвої поведінки; } \\
\text { будує діалогічну взаємодію відповідно до ситуації спілкування; } \\
\text { враховує соціолінгвістичні характеристики адресата. }\end{array}$ \\
\hline \multirow[t]{4}{*}{$\begin{array}{l}\text { Спеціальні } \\
\text { компоненти }\end{array}$} & 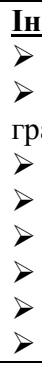 & $\begin{array}{l}\text { Iтивна взаємодія } \\
\text { будує репліки діалогу за нормами граматики китайської мови; } \\
\text { адекватно реагує на ініціативну репліку, будуючи реактивну репліку за правилами вимови і } \\
\text { и; } \\
\text { спонтанно висловлюється в діалозі; } \\
\text { демонструє відповідну мовленнєву поведінку у типових ситуаціях і залежно від адресата; } \\
\text { ставить запитання і дає відповідь; } \\
\text { оформлює репліку інтонаційно і за допомогою просодичних засобів; } \\
\text { запитує додаткову інформацію; } \\
\text { будує інформативно значуще висловлювання. }\end{array}$ \\
\hline & & $\begin{array}{l}\text { овальна взасмодія } \\
\text { ініціює репліку; } \\
\text { формулює прохання і побажання; } \\
\text { продовжує діалог, змінюючи тему; } \\
\text { виражає емоцію, передає враження. }\end{array}$ \\
\hline & $\frac{K}{\partial}$ & $\begin{array}{l}\text { тивна взаємодія } \\
\text { звертається до співрозмовника; } \\
\text { погоджується; } \\
\text { використовує засоби емотивного мовлення. }\end{array}$ \\
\hline & & $\begin{array}{l}\text { вна взаємодія } \\
\text { уточнює, перепитує, перебиває, утримує увагу співрозмовника; } \\
\text { переконує. }\end{array}$ \\
\hline
\end{tabular}

3 урахуванням вказаних вимог будується підсистема вправ для поетапного навчання усного китайського діалогічного мовлення в тематичному циклі занять. Кожен етап навчання має будуватися відповідно до тих видів діалогічної взаємодії, якими повинні оволодіти студенти, а також містити групи вправ, що передбачають дотримання принципу одного різновиду навчальних труднощів та принципу їх нарощування під час виконання операцій, які послідовно ускладнюються під час виконання підсистеми вправ.

Межі між описаними етапами є умовними, оскільки запропонована підсистема вправ для формування вмінь продукування діалогів є базовою та умовною. У реальному навчальному процесі більшість умінь формується комплексно і паралельно.

Представимо запропоновану підсистему вправ навчання продукування діалогів у таб. 4.

Таблиця 4. Підсистема завдань і вправ для навчання усного китайського діалогічного мовлення в межах виділених видів діалогічної взаємодії

\begin{tabular}{|c|c|c|c|}
\hline \multicolumn{4}{|c|}{ Типи діалогічної взаємодії } \\
\hline Інформативний & Стимулювальний & Кооперативний & Дискутивний \\
\hline \multicolumn{4}{|c|}{ Комунікативна мета } \\
\hline $\begin{array}{l}\text { Запит - інформація у відпо- } \\
\text { відь - повідомлення і сприй- } \\
\text { няття інформації }\end{array}$ & $\begin{array}{l}\text { Пропозиція (у формі прохання, } \\
\text { наказу, поради, спонукання) - у } \\
\text { відповідь: згода, незгода }\end{array}$ & $\begin{array}{l}\text { Обмін судженнями / } \\
\text { думками / враженнями }\end{array}$ & $\begin{array}{l}\text { Обговорення - } \\
\text { взаємопереконання / обгрунту- } \\
\text { вання власної точки зору }\end{array}$ \\
\hline \multicolumn{4}{|c|}{ Етап I (вправи і завдання рецептивно-репродуктивні, умовно-комунікативні) } \\
\hline \multicolumn{4}{|c|}{$\begin{array}{l}\text { Вправи з діалогами-зразками для читання, аналізу, аудіювання, в яких тренується складна вимова, синтаксис, стилістика та } \\
\text { подається нова лексика }\end{array}$} \\
\hline \multicolumn{4}{|c|}{ Етап II (вправи і завдання рецептивно-продуктивні, умовно-комунікативні) } \\
\hline \multicolumn{4}{|c|}{$\begin{array}{l}\text { Вправи з діалогами для доповнення, заміни, комбінування із залученням визначеної лексики, виправлення, заміни граматичної } \\
\text { конструкції, вправи на синтаксичну і стилістичну корекцію }\end{array}$} \\
\hline \multicolumn{4}{|c|}{ Етап III (вправи і завдання продуктивні, комунікативні) } \\
\hline
\end{tabular}


Приклади вправ (завдань) на I етапі застосування діалогу-зразка.

Завдання 1. Мета: формування рецептивнорепродуктивних умінь діалогічного мовлення, формування умінь встановлювати тип діалогічної взаємодіï; розвиток лексичних та фонетичних навичок діалогічного мовлення.

Інструкція 1 (до прослуховування): Прослухайте діалог та встановіть його комунікативну мету (обмін думками, обговорення, стимулювання до певних дій, інформування тощо).

对话线索 : 新班主任来上课一自我介绍一宣布 考试成绩一发表议论

“为了扎根乱班中。千说万劝主意正, 管保谁来谁 气蒙。看她这次待的时间有多长! ”长 cháng（形容词） 很长长远长久 zhãng (动词) 生长成长长知识为 wéi（动词）大有可为认认为成为 wèi 介词）为人民服 务为虎作伥的 de (助 词) 谁的书我的祖国 de（形 容词）的确如此的当（恰当） dì（名词）目的八有的 放矢数 shǔ (动词) 数落〉数不清入数得着 shù（名词） 数据〉数量〉数额

Спосіб виконання: студенти слухають двічі діалог, потім - групове обговорення його комунікативної мети.

1. Кочергин И. В. Очерки лингводидактики китайського языка - М, Восток-Запад, 2006. - 190 с.

2. Шатилов С. Ф. Методика обучения немецкому языку в средней школе: Учеб. пособие для студентов пед. ин-тов по спец. №2 103 «Иностр.яз.» - 2-е изд., дораб. - М.: Просвещение, 1986. - 222 с.
Спосіб контролю: усна фронтальна форма контролю з боку викладача.

Після обговорення

Викладач роздає роздрукований діалог.

Інструкція 2 (після прослуховування): Одночасно прослухайте діалог $i$ читайте його друкований варіант. Зверніть увагу на просодичні моделі, випишіть невідому лексику, встановіть ї̈ значення. Підготуйте діалог до близького до тексту переказу у парах (потім поміняйтеся ролями).

Спосіб виконання: студенти слухають і читають діалог, визначають просодичні моделі, семантизують невідому лексику, заучують напам'ять максимально близько до тексту, тренуються в парах до переказу, потім - переказують вголос.

Спосіб контролю: усна форма контролю 3 боку викладача, самоконтроль та взаємоконтроль.

Висновки. Отже, на основі вищезазначеного можна зробити висновок, що підсистема вправ і завдань для навчання усного китайського діалогічного мовлення розроблена згідно з типами діалогічної взаємодії, якими є інформативний, стимулювальний, кооперативний та дискутивний. За критерієм спрямованості навчальної дії на видачу або отримання інформації до підсистеми вправ i завдань увійшли рецептивнорепродуктивні, репродуктивно-продуктивні та продуктивні вправи, а за критерієм комунікативності визначаються умовно-комунікативні, комунікативні вправи першого та другого рівнів.

\section{ЛIТЕРАТУРА}

3. Щукин А.Н. Современные интенсивные методы и технологии обучения иностранным языкам: Учебное пособие. - М.: Филоматис, 2008. - 188 с.

4. Arnett, R. C. Dialogic Education: Conversation about Ideas and Between Persons. SIU Press, 1997. - Education. - 266 p.

\section{REFERENCES}

1. Kochergin I.V. Chinese language Essays on didactics. - M, Vostok-Zapad, 2006. - 190 p.

2. Shatilov S.F. Methods of teaching the German language in high school: A manual for students of pedagogical institutes in the specialty №2103 «Inostr.yaz.» - 2nd edition. - M.: Prosveschenie, 1986. $-222 \mathrm{p}$.
3. Schukin A.N. Modern intensive methods and technologies of teaching foreign languages: Tutorial. - M.: Filomatis, 2008. $188 \mathrm{p}$.

4. Arnett, R. C. Dialogic Education: Conversation about Ideas and Between Persons. SIU Press, 1997. - Education. - 266 p.

Methods of formation and development of speech competence in Chinese oral dialogic speech of future synologists at intermediate level of language training

O. Asadchykh, Ma Min, V. Filonova

Abstract. The article deals with the peculiarities of the technique of formation and development of speech competence in oral Chinese dialogic speech of future synologists at the average level of language training, identifies the types of dialogic interaction and presents a subsystem of exercises and tasks. The Chinese Oral Speech Exercises and Tasks subsystem has been developed according to the types of dialogic interaction that are informative, stimulating, cooperative and debatable. The subsystem includes receptivereproductive, reproductive-productive and productive exercises, and on the criterion of communicativeness - conditionallycommunicative, communicative exercises of the first and second levels.

Keywords: oral Chinese dialog, synologists philologists, Chinese language training in the HEE (Higher Education Establishments), types of dialogic interaction, subsystem of exercises and tasks. 